\title{
Study of Impact of over Tourism on Local society at Pilgrimage Destination with reference to Mathura and Vrindavan
}

\author{
Ritesh Sharma \\ Assistant Professor, GLA University, Mathura \\ and Research Scholar Jiwaji University, \\ Gwalior
}

\begin{abstract}
The widespread of visitor to a particular destination has led to a situation or problem, referred as over tourism, but now it's the foremost common phrase for describing the negative impacts of tourism. Locals particularly destinations, have felt the impact of expanding outsiders which they need been compelled to manage the pressure altogether directions like environment, economic furthermore because the culture. Hence, the aim of the study is to clarify the results of overcrowding on the area people in pilgrimage destination. The target of this study is to see the challenges or opportunities faced by area people with relevancy over tourism. This research is distributed at two important pilgrimage sites of western Uttar Pradesh Mathura and Vrindavan. This paper provides a critical structure of issues faced by the locals and a few of the suggestion to beat the situations.
\end{abstract}

Keywords - Pilgrimage Destinations; Impact; Local community; Over tourism, Mathura and Vrindavan

\section{INTRODUCTION}

\section{India and Spiritual Tourism}

It has now become a new fashion to practice to know and follow the distant religions and spiritual practices. Especially in western country like US Yoga studies are implanted as a separate branch of study which is able to bring peace and happiness in their life. It is not surprising that some of these people again interested in going to the place of their new beliefs and, therefore, are involved in "Spiritual Tourism. Not surprisingly India has become the most popular destination for this purpose.

Visits in India take travelers to the next level in their life. India includes many spots and destination of spiritual and religious importance. To name few 'Golden Temple (Amritsar); 'Varanasi' or 'Kashi', 'Mathura' \& 'Vrindavan' (Uttar Pradesh) (which are the area of our study); 'Somnath'\&'Dwarka' (Gujarat); 'Darga Khwaja Saheb' (Ajmer); 'Haridwar'\&'Rishikesh', 'Gangotri' (Uttarakhand); 'Rameshwaram' (Tamil Nadu); Jagannath Puri (Orissa); Tirupati (Andhra Pradesh); also, Bodh Gaya (Bihar) etc. Now let us focus on the area of our study that is Mathura and Vrindavan.

Over tourism could be a new term for old problem, namely visiting of more number of people to a particular place, which is bigger than the carrying capacity led to negative perception for all 
the stakeholders. (Butler, 2006) John Ruskin complained of the presence and impact of holiday makers in Venice within the mid-19th Century and also the transformative effects of heavy visitation on destination are noted for run out a century.

(Segota, 2017)Large quantities of travelers can upset the individuals of the site, particularly if salary comes from the travel industry blast doesn't gush down anyway rather pours out of the state. Accordingly, it had been contended that if the region individuals imagine that travel industry improvement gives more noteworthy positive effects than negative ones at that point they're probably going to help.

The recent research by Seraphin, Sheeran, \& Pilato (Seraphin, 2018) studied about over tourism and also the fall of Venice as a destination.

Thus, studies on identifying the impact of over tourism towards area people in heritage city especially at Mathura and Vrindavan are essential to bridge the gap of information. Hence, the objectives of this can be to see the challenges or opportunities faced by area people with relevancy over tourism

\section{REASONS AND PLACES TO VISIT AT MATHURA AND VRINDAVAN}

Community goes to religious trip for having several imaginations or visions very frequently we go on religious tour when some change takes place in our life or in our respective relationship if transformation has taken place. A few are there who wishes to achieve the mental ease along with this they also want to get the spirituality in their life to be the part of our Indian culture and religion. If someone has committed any mistake in their life for the same reason also they use to approach the religious place to have the forgiveness. With the view to meet the new people coming from different or diverse culture is also the prime demand of spiritual tourism in our country.

- To have the feeling of mighty god

- To get the assistance in the worse time

- To be associated to the truth and faith

- To feel as being the part of spirituality

- To be associated to the reality of this universe

- To be the part of some holy task associated to the all mighty

\section{Mathura}

Located on the edge of the sacred Yamuna brook in the UP (Utter Pradesh), Mathura is famed for being the origin of Krishna. Mathura in midst of Braj. It is just an hour's drive from Agra. The entire region is speckled with splendid temples, dedicated to different aspects of Lord Krishna's life. The city, with its rich history and culture, is a pilgrimage spot for Hindus. Some of the famous temples of Mathura are Shri Krishna Janmsthan Temple, Dwarikadhish Ji Temple, Vishram Ghat, Bhuteshwar Temple etc. Lord Krishna loved milk and butter, and hence Mathura is famous for its milk-based products, especially the "Peda", a soft milk sweet that's fresh and melts in your mouth. Handicrafts and a wide variety of trinkets that are related to the story of Lord Krishna and his childhood Lilas are 
also famous here. The city comes to life during the numerous festivals that are celebrated throughout the year. The other places of interest in Mathura are the Mathura Museum, Govardhan Hill, and KansQila.

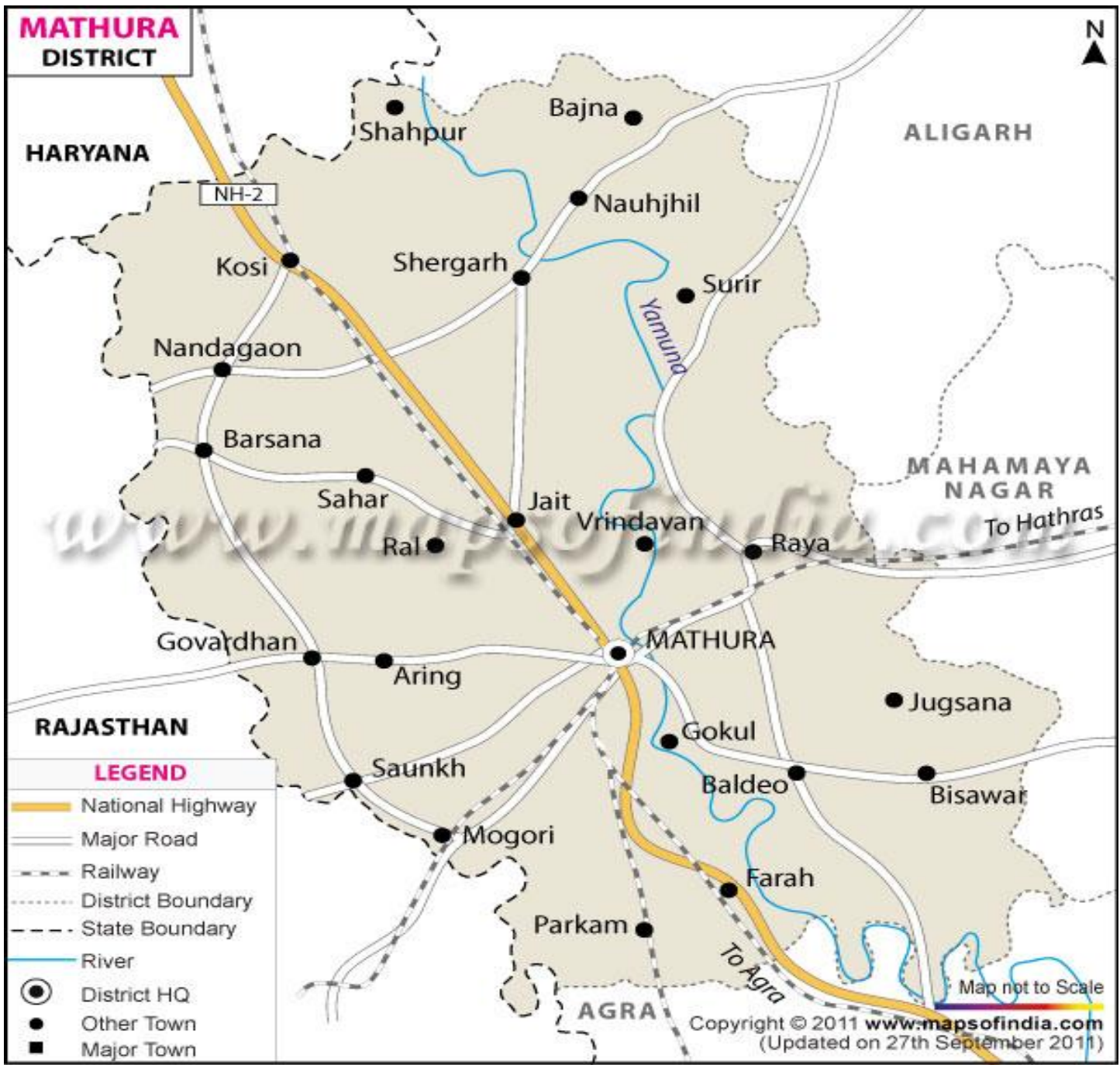

Source: www.mapsofindia.com

\section{Vrindavan}

Vrindavan is known to be the house of Lord Krishna. It is also a busy tourist site for people looking for spiritual and religious growth in their life. This town is also been called as the town of temples and it exists in Mathura district of western Uttar Pradesh. This place has lot of natural greenery; although it is a small town but it is able to draw attention of pilgrims from all over the world.

In Vrindavan there is a good mix of old and new temples. It is a the culturally strong and traditionally-inclined the town which hypnotizes the senses of pilgrims and tourists. The range of its temples are either they are modern or old they are all spread throughout the Vrindavan as a landscape.. 
The prominent temples of Vrindavan includes- Bankey Bihari temple, Radha Damodar Temple, ISCON temple which is also known as angregon ka temple, Nidhivan, Mote Ganesh Temple, Katyani Devi Temple, Meera Bai Temple, Govind Dev temple Rang devji Temple, Madan Mohan Temple, , Vrindavan Chandrodaya Mandir, etc.,

These temples are the major point of tourist rather we can say the Spiritual attractions among Pilgrims and tourists who visit this place. This place is very peaceful and is a place of importance for those who desire to have a connection with their inner consciousness. Vrindavan is one of the oldest town of Braj area the reference of which is mentioned in Hindu scriptures.

Rising Yamuna River, the city in Agra has been linked with the history of India, since ancient times. This beautiful city is a perfect example of India's rich culture and heritage. It is mentioned in the epic tale Mahabharata as 'Agravana,' literally translated as ' border of the forest.' Home to wonder of the globe, the Taj Mahal, Agra is a globetrotter's haven. You can say that the Mughals have left a permanent impression on this city which is evident in the various mausoleums and forts found here. Be mesmerized by the sprawling and majestic Agra Fort. Its many palaces, mosques, and mausoleums are a proud testimonial of Mughal architecture. The legends of the Mughal Emperor Akbar and his fabled courtiers are still kept alive at the ruins of Fatehpur Sikri, which is located on the outskirts of Agra. The chowks (marketplaces) and alleyways found in the city are usually the hub of many activities. Years ago, all the artisans and craftsmen who toiled to make the Taj Mahal a reality set up their houses nearby, creating the network of alleyways known as Taj Ganj.

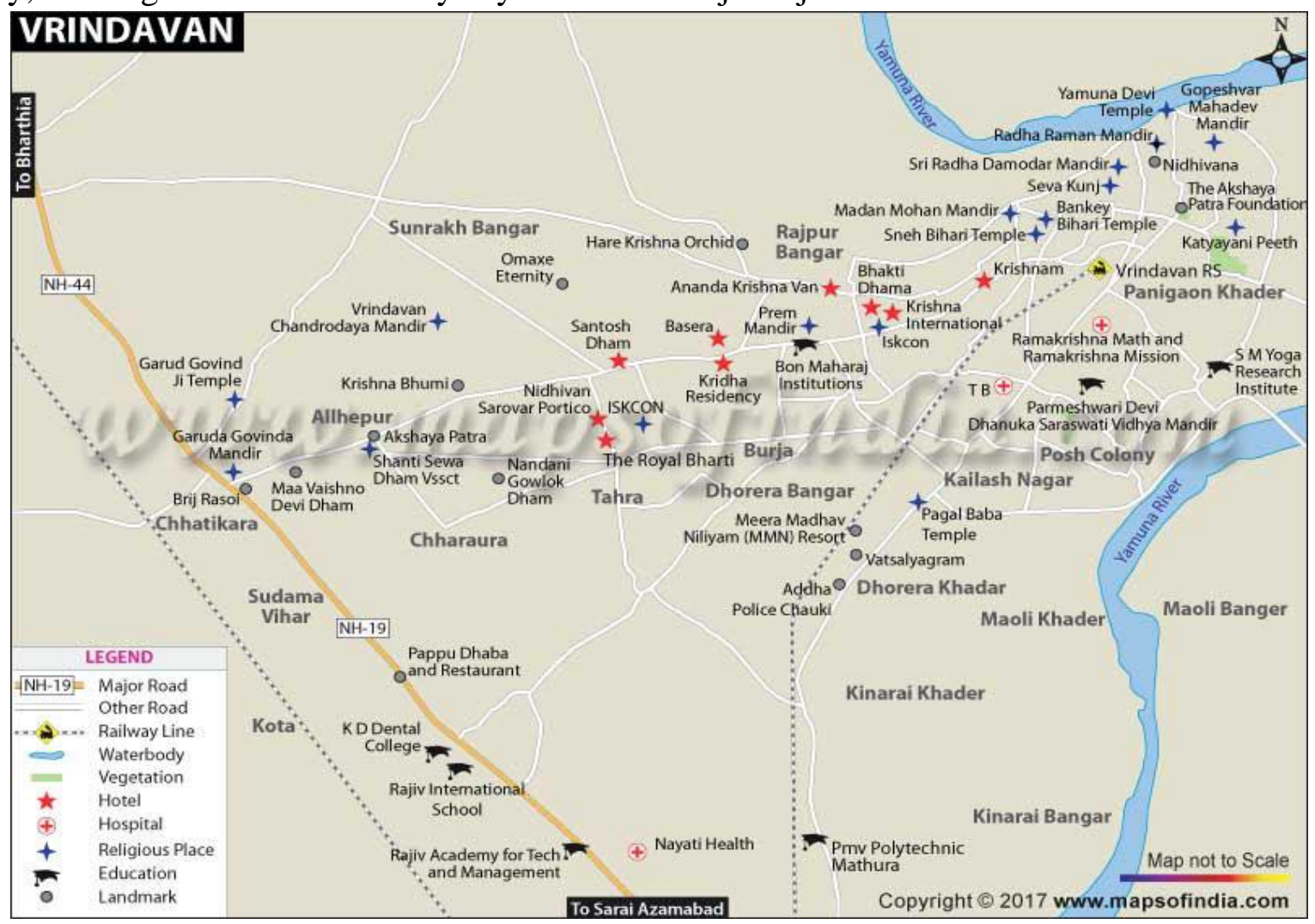




\section{REVIEW OF LITERATURE}

As stated by (Straitwell, 2006; Brown, 1998; Cohen, 1979; Burton, 1855) spiritual travel industry is more current scholastic idea by all accounts, yet it is positively not another wonder. According to the research work of Haq, Wong and Jackson (2008), and Haq and Jackson (2006 a, b and c, 2007), the profound vacationer is somebody who visits a particular spot out of the usual condition, with the expectation of deep importance which may lead to development.

In the travel industry advertisers consistently attempt to get familiar with the mentality and conduct of visitors to adequately plan and offer their travel industry offers (Kotler et al, 2008; Morgan et al, 2004; Morrison, 2002). These analysts have distinguished a few attributes of vacationers that help in structuring better promoting techniques.

Apart from this, travel industry is apparently a more state-of-the-art academic idea so far it is emphatically not another wonder as expressed by (Eade, 2006). In light of survey of writing, Hernandez-Avila (1996), this investigation portrays traveler is a person who visits a specific destination or place out of the standard condition, with the goal of journey - which means as well as development, with no plane strict imperative, \& could be strict or non-strict in nature, yet inside the Divine setting, paying little heed to the fundamental thought process in voyaging. Increments in strictly roused travel have agreed with the development of the travel industry in the forefront period Lloyd (1998), and despite the business and its "related practices connect with strict life and the establishments of religion in each side of the world" Bremer (2005), Vukonić (1998) contends that strict the travel industry is a champion among the most understudied zones in the travel industry explore. "Quality the travel industry encounters" is a term always used by goals and associations engaged with the travel industry and accommodation inquires about, arranging, arrangement, the board, showcasing and conveyance. Its significance is by verifiably or implicitly expected as opposed to characterized (Jennings, 2006) .Most of the investigations into visitor fulfillment in the travel industry have concentrated on figuring out the administrative traits, as these are related to the needs of the clients. From an advertising point of view, consumer loyalty is accomplished at the point when their needs and needs are satisfied Hadjiphanis, (2000) states, there is a for the most part broad comprehension in the academic articles that the arrangement of administration quality is worried about accomplishing consumer loyalty. Gaurav and Jagtap, (2014) claims Religious the travel industry have a significant future in a country like India since it is lavishly honored as a place happiness and peace. Off late the possibility of otherworldly the travel industry has moved from its center thought process to likewise obliging a business intention and in this way improved journey offices/administrations have turned out to be vital for the guests to hallowed places and heavenly goals to meet the many and shifted desires and impression of the pioneers and to help the achievement of pioneer goal and sanctums when all is said in done (Ahmed, 1992). Weidenfeld, (2006) suggests a consideration on gathering the phenomenal desire $\&$ needs of the travelers.

Vukonic, (1996), in an investigation on strict the travel industry, suggests modernizing journey goals with the changing needs of the visitors and providing good food to the guests so they visit the pace again and again. 
The sense and power of the effect rely on both vacationer's numbers and furthermore the qualities of the location. (Maria, 2017)The effect could likewise be physical, monetary or social and it will be either during a positive or negative sense.

Generally, the travel industry area is connected to improving spots for individuals to quantify and better places for individuals to go to. Teo et al. states (Teo CBC, 2014), it's just the obligation of 1 component or assembling yet associates with the obligation of all partners in the travel industry like the sightseers, the travel industry associations, neighborhood networks, arranging specialists, transport administrators, non-legislative associations and focal and local government. The partners are to accept obligation for their exercises and furthermore the impacts of their exercises. A perception that travel industry research zeroed in on the positive parts of the travel industry, accentuated the negative and offset level with the precise methodology.

\section{OBJECTIVES OF THE STUDY}

The most objectives of the study is to analyses weather the over tourism affect the local residents resources at Mathura and Vrindavan of western Uttar Pradesh. Hence the questionnaire structured supported their housing, business life and everyday life. Supported this we develop objectives to check the impact of over tourism on Western Uttar Pradesh to seek out whether over tourism affect the local residents.

\section{IV.HYPTHESIS OF THE STUDY}

\footnotetext{
$H_{0} H_{0}$ : Over tourism doesn't affect the area people with relevancy respondents Age ${ }^{H_{1} H_{1}}$ : Over tourism affect the area people with relevancy respondents Age.
}

\section{METHODOLOGY}

The quantitative approach was wont to evaluate the impact of over tourism within the area people at Mathura and Vrindavan of western Uttar Pradesh. This approach was selected supported the retrieved data. Therefore, a sampling technique had been wont to the entire numbers of 64 respondents participated within the place of research study. The info from the quantitative survey were analysed using SPSS Version 25. The info was compiled to get ends up in terms of Frequency, Percentage, Mean and a method ANOVA.

\section{DATA ANALYSIS AND RESULT}

This section describes the findings of the study. Following table shows the results, over tourism affect the local community with respect to the respondent's age.

\begin{tabular}{|c|c|c|c|c|c|c|c|}
\hline $\begin{array}{l}\text { Questio } \\
\text { ns }\end{array}$ & \begin{tabular}{l}
\multicolumn{1}{c}{ Age } \\
Catego \\
ry
\end{tabular} & $\mathbf{N}$ & Mean & $\begin{array}{c}\text { Std. } \\
\text { Deviatio } \\
\text { n }\end{array}$ & F & $\mathbf{P}$ & $\begin{array}{l}\text { Hypothesis } \\
\text { Accepted }\end{array}$ \\
\hline \multirow{3}{*}{$\begin{array}{l}\text { Housing } \\
\text { Characteristics } \\
\text { improve } \\
\text { satisfaction Level }\end{array}$} & $\begin{array}{c}\text { Below } \\
25\end{array}$ & 11 & 1.5455 & .82020 & \multirow{3}{*}{3.177} & \multirow{3}{*}{0.020} & \multirow[b]{3}{*}{$H_{1}$} \\
\hline & $25-30$ & 30 & 1.3333 & .60648 & & & \\
\hline & $30-40$ & 17 & 1.2941 & .58787 & & & \\
\hline
\end{tabular}




\begin{tabular}{|c|c|c|c|c|c|c|c|}
\hline & $40-50$ & 5 & 2.4000 & .89443 & & & \\
\hline & $\begin{array}{c}\text { Above } \\
50\end{array}$ & 1 & 1.0000 & & & & \\
\hline & Total & 64 & 1.4375 & .70991 & & & \\
\hline \multirow{6}{*}{$\begin{array}{l}\text { Price and Rent of } \\
\text { house } \\
\text { availability and } \\
\text { rents have } \\
\text { increased }\end{array}$} & $\begin{array}{c}\text { Below } \\
25\end{array}$ & 11 & 2.0909 & .94388 & \multirow{6}{*}{3.022} & \multirow{6}{*}{0.025} & \multirow{6}{*}{$H_{1}$} \\
\hline & $25-30$ & 30 & 1.7333 & .82768 & & & \\
\hline & $30-40$ & 17 & 2.4706 & .79982 & & & \\
\hline & $40-50$ & 5 & 2.6000 & .89443 & & & \\
\hline & $\begin{array}{c}\text { Above } \\
50\end{array}$ & 1 & 1.0000 & & & & \\
\hline & Total & 64 & 2.0469 & .89849 & & & \\
\hline \multirow{6}{*}{$\begin{array}{l}\text { Overcrowding } \\
\text { disturbs the } \\
\text { daily life }\end{array}$} & $\begin{array}{c}\text { Below } \\
25\end{array}$ & 11 & 1.5455 & .82020 & \multirow{6}{*}{3.034} & \multirow{6}{*}{0.024} & \multirow{6}{*}{$H_{1}$} \\
\hline & $25-30$ & 30 & 1.3667 & .61495 & & & \\
\hline & $30-40$ & 17 & 1.2941 & .58787 & & & \\
\hline & $40-50$ & 5 & 2.4000 & .89443 & & & \\
\hline & $\begin{array}{c}\text { Above } \\
50\end{array}$ & 1 & 1.0000 & & & & \\
\hline & Total & 64 & 1.4531 & .71113 & & & \\
\hline \multirow{6}{*}{$\begin{array}{l}\text { Work related } \\
\text { Stress } \\
\text { affecting } \\
\text { professional } \\
\text { life }\end{array}$} & $\begin{array}{c}\text { Below } \\
25\end{array}$ & 11 & 1.8182 & .98165 & \multirow{6}{*}{0.686} & \multirow{6}{*}{0.604} & \multirow{6}{*}{$H_{0}$} \\
\hline & $25-30$ & 30 & 2.0000 & .87099 & & & \\
\hline & $30-40$ & 17 & 2.0588 & .89935 & & & \\
\hline & $40-50$ & 5 & 2.4000 & .89443 & & & \\
\hline & $\begin{array}{c}\text { Above } \\
50\end{array}$ & 1 & 1.0000 & & & & \\
\hline & Total & 64 & 2.0000 & .89087 & & & \\
\hline \multirow{6}{*}{$\begin{array}{l}\text { Behaviour of } \\
\text { tourists in public } \\
\text { creates negative } \\
\text { impacts }\end{array}$} & $\begin{array}{c}\text { Below } \\
25\end{array}$ & 11 & 1.5455 & .82020 & \multirow[t]{4}{*}{1.165} & \multirow[t]{4}{*}{0.336} & \multirow{4}{*}{$H_{0}$} \\
\hline & $25-30$ & 30 & 1.8333 & .87428 & & & \\
\hline & $30-40$ & 17 & 2.0000 & .93541 & & & \\
\hline & $40-50$ & 5 & 2.4000 & .89443 & & & \\
\hline & $\begin{array}{c}\text { Above } \\
50\end{array}$ & 1 & 1.0000 & & & & \\
\hline & Total & 64 & 1.8594 & .88850 & & & \\
\hline
\end{tabular}

Table 1 - Impact of over tourism with regards to respondents Age

Based on the Table $153 \%$ of them is male and another $47 \%$ of the respondents are female. In that majority of the respondents $47 \%$ are $25-30$ age group category people, $27 \%$ are from $30-$ 
40 age group, $17 \%$ of them below 25 age group category from the overall respondents of the study.

$68.8 \%$ are agreed, $18.8 \%$ are neutral and the remaining $12.5 \%$ of the respondent's disagrees the statement and the one way ANOVA results $\{\mathrm{F}(3.177), \mathrm{p}(.020)<0.05\}$ uncovered that housing characteristics improve satisfactory level because of over tourism which means the respondents agrees the improvement in housing characteristics. Hence ${ }_{1} H_{1}$ is accepted.

Majority of $42.2 \%$ are disagreed, $37.5 \%$ are agreed and the remaining $20.3 \%$ of the respondent's says neutral for the statement and the one way ANOVA results $\{\mathrm{F}(3.022), \mathrm{p}(.025)$ $<0.05\}$ uncovered that price and rent of house availability have increased because of over tourism which means the respondents agrees that there is increase in rents. Hence ${ }_{1} H_{1}$ is accepted.

$67.2 \%$ are agreed, $20.3 \%$ are neutral and the remaining $12.5 \%$ of the respondent's disagrees the statement and the one way ANOVA results $\{\mathrm{F}(3.034), \mathrm{p}(.024)<0.05\}$ uncovered that overcrowding affects the daily life of the locals. Hence ${ }_{1} H_{1}$ is accepted.

For the statement work related stress affecting professional life because of over tourism $39.1 \%$ of the respondents agree as well as disagreed and the remaining $21.9 \%$ said neutral, one way ANOVA results $\{\mathrm{F}(0.0686), \mathrm{p}(.0604)<0.05\}$ was not significant, which means that the respondents not accepted the statement. Hence ${ }_{0} H_{0}$ is accepted.

$46.9 \%$ are agreed, $20.3 \%$ are neutral and the remaining $32.8 \%$ of the respondent's disagrees the statement and the one way ANOVA results $\{\mathrm{F}(1.165), \mathrm{p}(.336)<0.05\}$ was not significant which means that the respondents disagree the statement. Hence ${ }_{0} H_{0}$ is accepted.

\section{VII.CONCLUSION}

The findings are revealed that in some aspects over tourism is affected the local communities in this study based on the respondents response the housing facilities like water, environment are improved as well as the rent and availability of the house are also increased some of the local community are facing issues regarding the increase of rent in the particular pilgrimage destination, also it affects the daily life of the local community.

On the other side it will not affect the majority of the local resident's professional life and also the behavior of visitors in the public place but in some parts the behavior of the visitor will make the negative impact for the host in the particular at Mathura and Vrindavan of western Uttar Pradesh. From this findings successfully achieve the objectives of the study. 


\section{REFERENCES}

1. R. Butler, The Tourism Area life Cycle, Clevedon: Channel view publications, 2006.

2. T. M. T. K. K. Segota, "The impact of residents informedness and involvement on their perceptions of tourism impacts: the case of Bled," Journal of Destination Marketing Management, vol. 6, no. 3, pp. 196-206, 2017.

3. C. p. Borg JVD, "Tourism in European Heritage Cites," Annals of Tourism Research, vol. 23, no. 2, pp. 306-321, 1996.

4. H. S. P. P. M. Seraphin, "Over tourism and the fall of Venice as a destination," Journal of Destination Marketing and Management, pp. 1-3, 2018.

5. R. O. N. Thomas, "The ( almost) imperceptible impact of tourism research on policy and practice," Tourism Managment, vol. 9, no. 8, pp. 379-389, 2017.

6. G. C.-v. M. Y. C. Maria, "Cultural Heritage and Urban Tourism:Historic City centres under pressure,"

7. Sustainability, vol. 9, no. 8, pp. 1-19, 2017.

8. Gupta, R. (2004): "Impact of Tourism in changing cultural landscape of Katra with special reference to Mata Vaishno Devi Shrine." University of Jammu. PP. 19.

9. Singh, J. (2004): "The Economy of Jammu and Kashmir." Radha Krishan Anand and Co., Jammu. PP. 223.

10. Singh, S. (1994): “Cultural Tourism and Heritage Management." Rawat Publications, Jaipur, India. PP. 15.

11. Chauhan, V. and Khanna, S. (2006): "Terrorism and Tourism in J\&K: An Empirical study."

12. International Tourism issues and Challenges: (ed. Bhardwaj D.S., Choudhary, M., Boora, S.S. Kamra, K.K., Kumar, R.B., Chand, M., and Taxak. R.H. Kanishka Publishers, Distributors, New Delhi. PP. 97-310.

13. Kotler, P., Bowen, J. T., and Makens, J. (2008).Marketing for hospitality and tourism. $8^{\text {th }}$ Edition. New Jersey: Prentice-Hall, Inc.

14. Lloyd, D.W. (1998). Battlefield Tourism. New York: Berg.

15. Smith, K. A. (2007). Distribution channels for events: Supply and demand-side perspectives. Journal of Vacation Marketing, 13(4), 321-333.

16. Vukonić, B. (1998). Religious tourism: economic value or an empty box? Zagreb International Review of Economics and Business

17. Weidenfeld, A. (2006). Religious needs in the hospitality industry. Tourism and Hospitality Research

18. Akhtar, Javiad, "Tourism Management in India”, Ashish Publishing House, New Delhi, 1990

19. Anand, M.M., "Tourism and Hotel Industry in India", Prentice Hall of India Pvt. Ltd., New Delhi, 1976

20. Anthony Edward, "International Tourism Forecasts to 1995", EIU, 40 Duke Street London WIM5DG, UK.

21. Archer, B.H., "Demand Forecasting in Tourism", University of Wales Press, Cardiff, 1974. 